\title{
WAWANCARA KLINIS UNTUK MENGATASI HAMBATAN PENALARAN MATEMATIS SISWA DALAM PENJUMLAHAN PECAHAN DENGAN PENYEBUT YANG BERBEDA DI SMP PONTIANAK
}

\author{
Sandie \\ Prodi Pendidikan Matematika STKIP PGRI Pontianak \\ sandiendie@gmail.com
}

\begin{abstract}
ABSTRAK
Penelitian ini bertujuan untuk mengetahui bagaimana wawancara klinis dapat mengatasi hambatan penalaran matematis siswa dalam penjumlahan pecahan dengan penyebut yang berbeda di SMP Pontianak. Subyek dipilih dengan menggunakan teknik pengambilan sampel nonprobality sampling yaitu dengan purposive sampling dengan subyek penelitian 6 siswa yang mengalami masalah dalam menyelesaikan masalah matematika pada materi operasi penjumlahan pecahan dengan penyebut yang berbeda dengan pre-test di bawah KKM yakni 70. Metode penelitian deskriptif lebih tepatnya rancangan penelitian seperti ini disebut penelitian deskriptif analitik berorientasi pemecahan masalah. Instrumen pengumpul data berupa tes tertulis dalam bentuk essay dan pedoman wawancara klinis. Data menunjukkan bahwa hambatan penalaran siswa dalam operasi penjumlahan pecahan dengan penyebut yang berbeda sebelum diberikan wawancara klinis banyak mengalami kesalahan konsep, prosedur, dan perhitungan. Setelah diberikan wawancara klinis menunjukkan siswa yang mengalami kesalahan konsep, prosedur, dan perhitungan dapat terminimalisir secara signifikan. Disarankan bagi para guru di sekolah diharapkan dapat menerapkan wawancara klinis kepada siswa yang kurang mampu dalam hal belajar.
\end{abstract}

Kata Kunci: Wawancara Klinis, Penalaran Matematis, Pecahan.

\section{PENDAHULUAN}

Ada beberapa prinsip pembelajaran standar menurut National Council of Teacher of Mathematics (NCTM), antara lain yaitu the equity principle (NCTM, 2000). Di dalam prinsip ini penekanannya adalah pembelajaran yang dilaksanakan oleh guru wajib memberi peluang yang sama bagi setiap untuk dapat belajar matematika secara baik.

Namun demikian, kenyataan menunjukkan bahwa tidak semua siswa mendapat kesempatan yang sama dalam mempelajari matematika dengan baik. Dalam setiap pelaksanaan proses pembelajaran, guru cenderung memperhatikan siswa yang kurang memahami materi, hanya menyampaikan materi dan tidak mengetahui kesulitan yang dihadapi siswa terhadap materi tersebut. Oleh karena itu, perlunya dipilih pembelajaran secara individual untuk mengungkapkan dan mengatasi hambatan apa yang dialami oleh siswa.

Dilihat dari kenyataan di lapangan, dalam proses pembelajaran guru masih banyak menggunakan model pembelajaran klasikal tanpa dilengkapi dengan model pembelajaran individual. Jalannya proses model pembelajaran klasikal ini lebih terpusat kepada guru dan hanya dapat diikuti siswa yang memiliki kemampuan yang tinggi saja. Akibatnya, siswa yang memiliki kemampuan rendah tidak mendapatkan kesempatan untuk mengungkapkan apa yang membuat 
mereka tidak paham terhadap materi yang diajarkan.

Salah satu materi yang sulit dipahami oleh siswa adalah penjumlahan pecahan. Meskipun penjumlahan pecahan ini sudah dipelajari di SD (Sekolah Dasar), tetapi kenyataannya siswa sering mengalami hambatan dalam menyelesaikan penjumlahan pecahan, terutama dalam penjumlahan pecahan dengan penyebut yang berbeda. Berdasarkan hasil pra riset dengan guru bidang studi matematika SMP Negeri 14 Kota Pontianak, yang menyatakan bahwa hasil belajar mata pelajaran matematika khususnya pada materi penjumlah pecahan masih dinyatakan lebih dari $50 \%$ belum memenuhi standar nilai KKM yaitu 70. Dari fakta-fakta ini dapat ditarik kesimpulan bahwa kompetensi penjumlahan pecahan masih kurang.

Meskipun usaha sering dilakukan untuk mengatasi hambatan kemampuan dalam penjumlahan pecahan, tetapi hambatan kemampuan dalam penjumlahan pecahan sampai saat ini masih dialami oleh siswa. Hambatan tersebut diduga dikarenakan oleh pembelajaran secara klasikal.

Rendahnya hasil belajar siswa pada mata pelajaran matematika khususnya meteri penjumlahan pecahan dapat disebabkan oleh beberapa hal. Salah satunya adalah hal yang berkaitan dangan bagaimana cara guru mengajar. Seperti yang sudah dipaparkan sebelumnya, dalam proses pembelajaran guru menerapkan pembelajaran secara klasikal. Guru mengganggap bahwa cara belajar siswa satu dengan siswa yang lainnya sama, padahal kemampuan siswa dalam memahami suatu pelajaran berbeda. Oleh karena itu, pembelajaran klasikal kurang membantu siswa dalam memahami pelajaran yang diberikan. Dengan menerapkan pembelajaran klasikal sebagaimana yang telah dikemukakan, maka penalaran siswa itu pun kurang terhadap materi penjumlahan pecahan, untuk itu diperlukan pembelajaran yang bersifat individual.

Dalam hal ini, altenatif cara untuk mengatasi hambatan penalaran matematis siswa dalam penjumlahan pecahan yang diusulkan peneliti adalah dengan melalui wawancara klinis. Menurut Buschman (2001: 266), wawancara klinis bisa memberikan umpan balik yang berguna bagi siswa dan berharga saat guru memberikan informasi diagnosis pada performa siswa. Selanjutnya Schoor (2000: 10) berpendapat bahwa wawancara klinis dapat membantu calon guru untuk mempertimbangkan pedekatan alternatif mengajar dan belajar matematika dan mengembangkan peningkatan kesadaran tentang cara-cara orang belajar matematika.

Ada beberapa penelitian yang menggunakan wawancara klinis, antara lain penelitian Christianti (2012), Barunawati (2012), dan Robeka (2012). Hasilnya menunjukkan bahwa penggunaan wawancara klinis dapat membantu kesulitan siswa dan adanya peningkatan hasil belajar. Dari penelitian yang menggunakan wawancara klinis sebagai alat bantu untuk memperbaiki sistem pembelajaran di sekolah tempat mereka kelakukan penelitian.

Wawancara klinis mempunyai 3 poin terpenting, yaitu membimbing, memberikan solusi dan yang paling penting adalah memahami seseorang. Dalam hal wawancara klinis dipandang metode yang tepat untuk pembelajaran 
individual terhadap siswa agar tidak adanya kesetaraan antara siswa. Menurut Sutrisno (dalam Christianti, 2012: 3), dalam wawancara klinis selain pewawancara mencoba untuk menggali apa yang dipikirkan siswa, dan siswa pun juga diberi kesempatan untuk meminta keterangan/penjelasan dari si pewawancara. Dengan cara ini terciptalah dialog antara pewawancara dengan siswa yang diwawancarai. Akibat dari dialog ini tidak saja pewawancara dapat mengetahui tingkat pengetahuan siswa saat itu, siswa pun dapat memperoleh bimbingan dari pewawancara.

Berdasarkan uraian yang telah dikemukakan, wawancara klinis dapat mengetahui tingkat pengetahuan siswa dan peneliti dapat menemukan solusi yang tepat untuk menopang penalaran matematis siswa dalam menyelesaikan masalah operasi penjumlahan pecahan dengan penyebut yang berbeda.

\section{METODE PENELITIAN}

Metode penelitian yang akan digunakan dalam penelitian ini adalah metode deskriptif analitik dengan bentuk penelitian studi kasus. Populasi dalam penelitian ini adalah seluruh siswa kelas VII SMP Negeri 14 Kota Pontianak.
Subyek dipilih dengan menggunakan teknik pengambilan sampel nonprobality sampling yaitu dengan purposive sampling dengan subyek penelitian siswa yang mengalami masalah dalam menyelesaikan masalah matematika pada materi operasi penjumlahan pecahan dengan penyebut yang berbeda dengan pre-test di bawah KKM yakni 70. Teknik yang digunakan untuk pengumpulan data yakni teknik pengukuran dan teknik komunikasi langsung. Alat pengumpul data yakni tes tertulis dengan bentuk essay sebanyak 3 soal dan pedoman wawancara klinis untuk menopang kesulitan siswa dalam menyelesaikan masalah matematika dalam operasi penjumlahan pecahan dengan penyebut yang berbeda. Teknik analisis data yakni melakukan analisis hambatan siswa dan analisis dampak wawancara klinis pada hasil pre-test dan post-test yang dikaitkan dengan wawancara kepada siswa.

\section{HASIL PENELITIAN DAN PEMBAHASAN}

Pemaparan data siswa yang telah mengikuti pre-test dapat dilihat pada Tabel 1.

Tabel 1. Hasil Pre-Test

\begin{tabular}{|c|c|c|c|c|c|c|}
\hline \multirow{2}{*}{ No. } & \multirow{2}{*}{$\begin{array}{l}\text { Kode } \\
\text { Siswa }\end{array}$} & \multicolumn{3}{|c|}{ Soal Pre-Test } & \multirow{2}{*}{$\begin{array}{l}\text { Skor } \\
\text { Total }\end{array}$} & \multirow{2}{*}{ Nilai } \\
\hline & & 1 & 2 & 3 & & \\
\hline 1 & $\mathrm{~A}$ & 0 & 2 & 0 & 2 & 16.7 \\
\hline 2 & $\mathrm{~B}$ & 0 & 0 & 0 & 0 & 0.0 \\
\hline 3 & $\mathrm{C}$ & 0 & 1 & 1 & 2 & 16.7 \\
\hline 4 & $\mathrm{D}$ & 2 & 1 & 0 & 3 & 25.0 \\
\hline 5 & $\mathrm{E}$ & 4 & 4 & 4 & 12 & 100.0 \\
\hline 6 & $\mathrm{~F}$ & 3 & 1 & 3 & 7 & 58.3 \\
\hline 7 & $\mathrm{G}$ & 0 & 0 & 0 & 0 & 0.0 \\
\hline 8 & $\mathrm{H}$ & 2 & 1 & 0 & 3 & 25.0 \\
\hline
\end{tabular}




\begin{tabular}{rrrrrrr}
\hline 9 & I & 2 & 4 & 2 & 8 & 66.7 \\
\hline 10 & J & 4 & 1 & 4 & 9 & 75.0 \\
\hline 11 & K & 4 & 4 & 4 & 12 & 100.0 \\
\hline 12 & L & 0 & 4 & 2 & 6 & 50.0 \\
\hline 13 & M & 4 & 4 & 2 & 10 & 83.3 \\
\hline 14 & $\mathrm{~N}$ & 4 & 4 & 4 & 12 & 100.0 \\
\hline 15 & $\mathrm{O}$ & 1 & 0 & 0 & 1 & 8.3 \\
\hline
\end{tabular}

Pada tabel 1 dapat kita lihat bahwa terdapat 5 siswa yang memenuhi nilai KKM dan selebihnya di bawah nilai KKM. Ini menunjukkan bahwa pemahaman siswa pada materi operasi penjumlahan pecahan pada siswa sebagian besar masih lemah. Untuk melihat distribusi kesalahan siswa pada tiap soal dapat dilihat pada Tabel 2.

Tabel 2. Distribusi Kesalahan Siswa

\begin{tabular}{|c|c|c|c|c|c|c|c|c|c|c|}
\hline \multirow{3}{*}{ No. } & \multirow{3}{*}{$\begin{array}{l}\text { Kode } \\
\text { Siswa }\end{array}$} & \multicolumn{9}{|c|}{ Jenis Kesalahan Siswa } \\
\hline & & \multicolumn{3}{|c|}{ Soal No. 1} & \multicolumn{3}{|c|}{ Soal No.2 } & \multicolumn{3}{|r|}{ Soal No.3 } \\
\hline & & KK & KP & $\mathrm{KPr}$ & KK & KP & KPr & KK & $\mathrm{KP}$ & KPr \\
\hline 1 & A & & $\sqrt{ }$ & & & $\sqrt{ }$ & & $\sqrt{ }$ & & \\
\hline 2 & $\mathrm{~B}$ & $\sqrt{ }$ & & & $\sqrt{ }$ & & & $\sqrt{ }$ & & \\
\hline 3 & $\mathrm{C}$ & & $\sqrt{ }$ & & & & $\sqrt{ }$ & & & $\sqrt{ }$ \\
\hline 4 & $\mathrm{D}$ & & $\sqrt{ }$ & & & $\sqrt{ }$ & & $\sqrt{ }$ & & \\
\hline 5 & $\mathrm{E}$ & & & & & & & & & \\
\hline 6 & $\mathrm{~F}$ & & $\sqrt{ }$ & & & & $\sqrt{ }$ & & $\sqrt{ }$ & \\
\hline 7 & G & $\sqrt{ }$ & & & $\sqrt{ }$ & & & $\sqrt{ }$ & & \\
\hline 8 & $\mathrm{H}$ & & $\sqrt{ }$ & & $\sqrt{ }$ & & & $\sqrt{ }$ & & \\
\hline 9 & I & & & $\sqrt{ }$ & & & & & & $\sqrt{ }$ \\
\hline 10 & $\mathrm{~J}$ & & & & & & $\sqrt{ }$ & & & \\
\hline 11 & $\mathrm{~K}$ & & & & & & & & & \\
\hline 12 & $\mathrm{~L}$ & & $\sqrt{ }$ & & & & & & & $\sqrt{ }$ \\
\hline 13 & $\mathrm{M}$ & & & & & & & & & $\sqrt{ }$ \\
\hline 14 & $\mathrm{~N}$ & & & & & & & & & \\
\hline 15 & $\mathrm{O}$ & $\sqrt{ }$ & & & & $\sqrt{ }$ & & & $\sqrt{ }$ & \\
\hline \multicolumn{2}{|c|}{ Jumlah } & 3 & 6 & 1 & 3 & 3 & 3 & 5 & 2 & 4 \\
\hline
\end{tabular}

Berdasarkan Tabel 2 kita dapat melihat didstribusi kesalahan siswa. Pada soal nomor 1 terdapat 3 siswa dengan kesalahan konsep, 6 siswa dengan kesalahan prosedural, 1 orang dengan kesalahan perhitungan. Pada soal nomor 1 terdapat $20 \%$ siswa dengan kesalahan konsep, $40 \%$ siswa dengan kesalahan prosedural, 6,67\% siswa dengan kesalahan perhitungan.
Pada soal nomor 2 terdapat 3 siswa dengan kesalahan konsep, 3 siswa dengan kesalahan prosedural, 3 siswa dengan kesalahan perhitungan. Pada soal dengan nomor yang sama terdapat masing-masing kesalahan dengan persentase sebesar $20 \%$.

Pada soal nomor 3 terdapat 5 siswa dengan kesalahan konsep, 2 siswa dengan kesalahan prosedural, 4 siswa dengan kesalahan perhitungan. Pada soal dengan 
nomor yang sama terdapat $33,33 \%$ siswa dengan kesalahan konsep, $13,33 \%$ dengan kesalahan prosedural, $26,67 \%$ dengan kesalahan perhitungan.

Siswa yang menjadi sampel dalam penelitian ini adalah sebanyak 6 siswa berdasarkan banyaknya kesalahan yang dilakukan dan skor yang diperoleh. Berdasarkan Tabel 2 yang dilakukan dan skor yang diperoleh yaitu A, B, G, H, J dan O.

Siswa yang telah dipilih menjadi sampel dalam penelitian, diberikan soal kembali sebanyak 3 butir soal operasi penjumlahan pada pecahan dengan penyebut yang berbeda.

Analisis kesalahan siswa pada subyek penelitian pada soal nomor 1 adalah 1 orang subyek penelitian bisa mengerjakan soal nomor 2. Dilihat bahwa 4 orang subyek penelitian tidak memahami konsep dan 1 subyek penelitian tidak mengetahui prosedur yang tepat dalam meyelesaikan soal penjumlahan pecahan yang penyebutnya beda.

Analisis kesalahan siswa pada subyek penelitian pada soal nomor 2 adalah 3 orang subyek penelitian melakukan kesalahan konsep dalam mengerjakan soal nomor 3 dan 2 orang subyek penelitian melakukan kesalahan yang sama, yaitu kesalahan prosedural sehingga mencari KPK tidak dilakukan dan tidak tepat dalam pengalian. serta 1 orang subyek melakukan kesalahan perhitungan kurang telitinya dalam operasi perkalian dengan pembilang pecahan, sehingga menghasilkan jawaban yang salah.

Analisis kesalahan siswa pada subyek penelitian pada soal nomor 3 adalah 4 orang subyek penelitian melakukan kesalahan yang sama yaitu kesalahan konsep, sehingga tidak mengetahui prosedur yang tepat dalam menjawab soal penjumlahan pecahan, dan 1 subyek penelitian melakukan kesalahan prosedur sehingga tidak mencari KPK dari penyebut pecahan.

Dari jawaban-jawaban yang telah diberikan oleh subyek penelitian dapat dilihat bahwa semua subyek penelitian kurang menguasai tentang penjumlahan pecahan. Berdasarkan wawancara dengan keenam subyek penelitian yaitu semua subyek merasa soal yang diberikan sulit. Subyek 2 merasa belum bisa dalam mengerjakan soal penjumlahan pecahan, yaitu dengan belum pahamnya menjumlahkan penjumlahan pecahan yang berpenyebut sama, belum pahamnya menyamakan penyebut dalam penjumlahan pecahan, belum memahami cara mencari pecahan senilai dari penjumlahan pecahan yang telah diketahui penyebutnya, dan belum pahamnya dalam menyederhanakn pecahan, serta belum pahamnya mengubah pecahan campuran kepecahan biasa. Subyek 1, 3, dan 6 merasa kebingungan dalam penjumlahan pecahan, yaitu belum pahamnya menyamakan penyebut dalam penjumlahan pecahan, belum memahami cara mencari pecahan senilai dari penjumlahan pecahan yang telah diketahui penyebutnya, dan belum pahamnya dalam menyederhanakn pecahan, serta belum pahamnya mengubah pecahan campuran kepecahan biasa. Subyek 4 belum memahami cara mencari pecahan senilai dari penjumlahan pecahan yang telah diketahui penyebutnya, dan tidak pahamnya dalam menyerdehanakan pecahan, serta belum pahamnya mengubah pecahan campuran kepecahan biasa. Subyek 5 dalam mengerjakan soal penjumlahan pecahan yang berpenyebut sama kurang teliti, begitu juga terhadap penjumlahan pecahan yang berpenyebut berbeda subyek kurang teliti terhadap operasi perkalian dan penjumlahan. Subyek 1, 2, 3, 4 dan 6 merasa bingung karena mereka belum paham akan konsep, prosedural dalam mengerjakan soal penjumlahan pecahan. Subyek 5 merasa bahwa yang dijawabnya itu sudah benar, maka tidak mengoreksi ulang lagi pengerjaannya, dikarenakan kurang telitinya terhadap jawaban tersebut, maka menyebabkan kesalahan dalam prosedur pengerjaaan soal penjumlahan pecahan. 
Setelah mendeskripsikan jenis kesalahan yang terjadi dalam menyelesaikan soal pre test, pada saat diberikan wawancara klinis dilakukan recheck bersama siswa menggunakan ketentuan-ketentuan yang sesuai dengan konsep penjumlahan pecahan. Recheck dilakukan agar siswa mengetahui bagaimana konsep penjumlahan pecahan yang sebenarnya. Peneliti dan siswa membahas satu per satu soal yang telah diberikan. Setelah mengerti siswa diberikan post test. Adapun hasil perbandingan antara pre-test dan post test dari ke 6 subyek penelitian dapat dilihat pada Tabel 3 .

Tabel 3. Skor Pre-Test dan Skor Post-Test subyek penelitian

\begin{tabular}{|c|c|c|c|c|c|c|c|c|c|}
\hline \multirow{2}{*}{ No } & \multirow{2}{*}{ Kode Siswa } & \multicolumn{3}{|c|}{ Skor Pre-Test } & \multirow{2}{*}{ Jumlah } & \multicolumn{3}{|c|}{ Skor Post-Test } & \multirow{2}{*}{ Jumlah } \\
\hline & & 1 & 2 & 3 & & 1 & 2 & 3 & \\
\hline 1 & A & 0 & 2 & 0 & 2 & 4 & 4 & 2 & 10 \\
\hline 2 & B & 0 & 0 & 0 & 0 & 4 & 3 & 4 & 11 \\
\hline 3 & $\mathrm{G}$ & 0 & 0 & 0 & 0 & 2 & 4 & 4 & 10 \\
\hline 4 & $\mathrm{H}$ & 2 & 1 & 0 & 7 & 4 & 4 & 4 & 12 \\
\hline 5 & $\mathrm{~J}$ & 4 & 1 & 4 & 9 & 4 & 4 & 3 & 11 \\
\hline 6 & $\mathrm{O}$ & 1 & 0 & 0 & 1 & 4 & 4 & 4 & 12 \\
\hline Jumlah & & & & & 19 & & & & 66 \\
\hline
\end{tabular}

Berdasarkan tabel 3 menunjukkan bahwa masing-masing subyek penelitian terdapat peningkatan hasil belajar, yaitu: siswa A memiliki skor pre-test sebesar 2 dan skor post-test menjadi 10 sehingga terdapat peningkatan sebesar $66,67 \%$. Siswa B memiliki memiliki skor pre-test sebesar 0 dan skor post-test menjadi 11 sehingga terdapat peningkatan sebesar 91,67\%. Siswa G memiliki skor pre-test sebesar 0 dan skor post-test menjadi 10 sehingga terdapat peningkatan $83,33 \%$. Siswa H memiliki skor pre-test sebesar 7 dan skor post-test menjadi 12 sehingga terdapat peningkatan sebesar $41,67 \%$. Siswa J memiliki skor pre-test sebesar 9 dan skor post-test menjadi 11sehingga terdapat peningkatan sebesar $16,67 \%$. Siswa O memiliki skor pre-test sebesar 1 dan skor post-test menjadi 12 sehingga terdapat peningkatan sebesar $91,67 \%$. Ini menunjukkan bahwa siswa mengalami peningkatan kemampuan matematis dalam menyelesaikan persoalan operasi penjumlahan pecahan dengan penyebut yang berbeda.

Kesalahan yang dilakukan siswa setelah diberikan wawancara klinis berkurang. Adapun jenis kesalahan yang dilakukan siswa pada post-test dapat dilihat pada Tabel 4 .

Tabel 4. Distribusi Kesalahan Siswa

\begin{tabular}{|c|c|c|c|c|c|c|c|c|c|c|}
\hline \multirow{3}{*}{ No. } & \multirow{3}{*}{$\begin{array}{l}\text { Kode } \\
\text { Siswa }\end{array}$} & \multicolumn{9}{|c|}{ Jenis Kesalahan } \\
\hline & & \multicolumn{3}{|c|}{ Soal No. 1} & \multicolumn{3}{|c|}{ Soal No.2 } & \multicolumn{3}{|c|}{ Soal No.3 } \\
\hline & & KK & KP & $\mathrm{KPr}$ & KK & KP & $\mathrm{KPr}$ & KK & $\mathrm{KP}$ & $\mathrm{KPr}$ \\
\hline 1 & A & & & & & & & & & $\sqrt{ }$ \\
\hline 2 & $\mathrm{~B}$ & & & & & & $\sqrt{ }$ & & & \\
\hline 3 & $\mathrm{G}$ & & & $\sqrt{ }$ & & & & & & \\
\hline 4 & $\mathrm{H}$ & & & & & & & & & \\
\hline 5 & $\mathrm{~J}$ & & & & & & & & & $\sqrt{ }$ \\
\hline 6 & $\mathrm{O}$ & & & & & & & & & \\
\hline
\end{tabular}


Wawancara klinis dilakukan dalam 3 kali pertemuan. Pertemuan pertama dilakukan pada tanggal 18 Oktober - 19 Oktober 2013. Pertemuan kedua dilakukan pada tanggal 19 dan 22 Oktober 2013. Pertemuan ketiga dilakukan pada tanggal 23 Oktober 2013. Wawancara ini dilakukan terhadap 6 orang subyek dan dilakukan secara bersamaan dan tidak bersamaan, serta pertanyaan yang diajukan secara individu. Berikut ini peneliti akan mendeskripsikan keadaan setiap subyek penelitian pada saat wawancara klinis.

Subyek 1, 2, 3, 4, 5 dan 6 pada penelitian ini masing-masing diberi kode A, B, G, H, J, O. Mereka adalah siswa SMP Negeri 14 Kota Pontianak. Alasan peneliti memilih A, B, G, H, J, dan O sebagai subyek penelitian dikarenakan mereka adalah 6 orang siswa yang kurang paham mengenai materi penjumlahan pecahan, ini dilihat dari hasil pre test yang telah diberikan yaitu dengan banyaknya kesalahan yang mereka lakukan, sehingga menghasil nilai dibawah KKM di sekolah tersebut. Adapun waktu yang diperlukan $\mathrm{A}, \mathrm{B}, \mathrm{G}, \mathrm{H}, \mathrm{J}$, dan $\mathrm{O}$ adalah melebihi dari waktu yang ditentukan yaitu $\geq$ 30 menit.

Pada wawancara klinis pertemuan pertama peneliti mencoba mengenal dan mengakrabkan diri dengan $\mathrm{A}, \mathrm{B}, \mathrm{G}, \mathrm{H}, \mathrm{J}$, dan O. Berdasarkan wawancara pertemuan pertama ini diperoleh informasi bahwa semua subyek penelitian adalah siswa yang ramah dan sopan. Pada wawancara klinis tahap pertama ini juga peneliti menanyakan kembali jawaban-jawaban mereka pada saat pre test, $\mathrm{A}, \mathrm{B}, \mathrm{G}, \mathrm{H}, \mathrm{J}$, dan $\mathrm{O}$ rata- rata memberikan keterangan bahwa meraka mengalami hambatan dalam melakukan penjumlahan pecahan yang mempunyai penyebut yang berbeda. Namun $\mathrm{O}$ mengatakan pada saat mengerjakan soal penjumlahan pecahan kurang teliti dalam mengerjakan soal tersebut.

Pada wawancara klinis pertemuan kedua, peneliti mencoba menggali pemikiran subyek penelitian dalam memahami konsep penjumlahan pecahan. Peneliti meminta subyek memperhatikan gambar, kemudian peneliti meminta subyek menentukan nilai pecahan dari gambar tersebut. Setelah itu peneliti meminta subyek menentukan hasil penjumlahan pecahan apabila nilai pecahan dari gambar dijumlahkan dengan nilai pecahan yang sama. Kemudian peneliti membantu subyek memahami penjumlahan pecahan dengan memberikan topangan kepada subyek cara menyelesaikan soal pre test yang benar. kemudian peneliti meminta subyek untuk mengerjakan soal yang diberi peneliti, untuk mengetahui pemahaman subyek tersebut. Dalam hal ini, ada subyek yang belum memahami konsep penjumlahan pecahan yang penyebutnya sama, yaitu subyek B dan J. Kemudian peneliti memberikan bimbingan terhadap subyek tersebut dalam memahami penjumlahan pecahan yang sudah mempunyai penyebut yang sama. Tetapi untuk 4 subyek lainya tidak mengalami hambatan dalam penjumlahan pecahan yang penyebutnya sama. Untuk subyek yang belum memahami dalam manyamakan penyebut penjumlahan pecahan, yaitu subyek A, B, G, dan O. Kemudian peneliti memberikan bimbingan terhadap subyek tersebut dalam memahami cara menentukan KPK dari penyebut pecahan. Tetapi untuk subyek $\mathrm{H}$ dan $\mathrm{J}$ tidak mengalami hambatan dalam menentukan KPK dari penyebut pecahan. Untuk subyek yang belum memahami pecahan senilai setelah menghasilkan penyebut yang sama, yaitu subyek A, B, G, H, dan O. peneliti memberikan bimbingan terhadap subyek tersebut dalam memahami pecahan senilai setelah menghasilkan penyebut yang sama. Untuk subyek A, B, G, dan $\mathrm{H}$ masih merasa kebingungan dalam mengubah pecahan campuran kebentuk pecahan biasa. Tetapi J dan $\mathrm{O}$ tidak mengalami hambatan dalam hal mengubah pecahan campuran kepecahan biasa. Kemudian peneliti memberikan bimbingan terhadap subyek yang mengalami 
hambatan dalam mengubah pecahan campuran kepecahan biasa. Untuk subyek A, $\mathrm{B}, \mathrm{G}, \mathrm{H}$ dan $\mathrm{O}$ belum memahami cara menyederhanakan pecahan. Kemudian peneliti memberikan bimbingan terhadap subyek tersebut dalam memahami cara menyederhanakan pecahan. Untuk subyek $\mathbf{J}$ kurang telitinya dalam operasi perkalian dan penjumlahan. Kemudian peneliti bimbingan $\mathbf{J}$ untuk lebih teliti dalam mengerjakan soal, jangan terburu-buru, dan periksa ulang lagi pekerjaan yang telah dilakukan. Setelah itu peneliti memberikan soal penjumlahan pecahan kepada subyek untuk dikerjakan dan dalam pengerjaannya dibimbing oleh peneliti. $\mathrm{B}, \mathrm{H}, \mathrm{J}$ dan $\mathrm{O}$ yang dengan cepat memahami sementara $A$, dan $G$ peneliti harus berulang-ulang kali menjelaskannya.

Pada wawancara klinis pertemuan ketiga, peneliti mencoba menanyakan kembali kepada subyek apakah sudah memahami penjumlahan pecahan, jika ada subyek yang masih belum paham mengenai penjumlahan pecahan, peneliti mencoba menjelaskan kembali konsep penjumlahan pecahan dan peneliti memberikan berberapa soal kepada subyek untuk dikerjakan lagi, jika terdapat hambatan dalam mengerjakannya subyek bertanya kepada peneliti. Setelah semua subyek memahami penjumlahan pecahan, peneliti memberikan post test kepada subyek untuk melihat peningkatan subyek tersebut.

Selama wawancara klinis yang dilakukan, peneliti dapat melihat bahwa $\mathbf{J}$ memiliki kemampuan yang paling tinggi. A, $\mathrm{B}, \mathrm{H}$, dan $\mathrm{O}$ memiliki kemampuan yang sedang. Sedangkan G memiliki kemampuan yang rendah diantara keenam subyek penelitian. Hal ini terlihat ketika wawancara klinis berlangsung, di mana $\mathrm{G}$ memerlukan waktu yang dalam dalam mengolah informasi yang disediakan oleh peneliti. Berikut ini akan disajikan beberapa perubahan yang terjadi pada semua subyek penelitian sebelum dan sesudah diberikannya bimbingan dalam mengatasi hambatan belajarnya menggunakan wawancara klinis.

Dari analisis hambatan subyek penelitian dapat dilihat bahwa semua subyek penelitian belum memahami materi penjumlahan pecahan, meskipun materi tersebut telah mereka pelajari sebelumnya. Hal ini dikarenakan semua subyek penelitian telah lupa terhadap penjumlahan pecahan yang telah diajarkan. Terlihat dari hasil pre test yang telah diberikan dan berdasarkan informasi yang diperoleh dari hasil wawancara, hambatan yang dialami subyek beragam.

Menurut Gulo dan Reber (dalam Muhibbin, 1999: 151) lupa adalah ketidakmampuan atau mengingat sesuatu yang pernah dipelajari atau dialami. Winkel (2005: 500) menyatakan bahwa gejala lupa mudah terjadi pada pengetahuan kognitif bila individu tidak berhasil mengkonstruksikan pengetahuannya sendiri atau tidak berhasil mengaitkan konsep-kosep yang dipelajarinya dengan konsep-konsep yang telah dimilikinya. Lupa akan terjadi apabila materi yang dipelajari tidak menarik, tidak diperlukan individu sehingga tidak dihiraukan.

Lupa disebabkan apabila informasi yang diterima hanya dapat bertahan dimemori jangka pendek saja dan tidak masuk ke dalam memori jangka panjang. Semb dan Elis (dalam Rahmad, 2009: 2) menyatakan bahwa faktor-faktor yang mempengaruhi memori jangka panjang terhadap pengetahuan yang telah dipelajari dalam kelas adalah tingkat kesulitan dari materi yang dipelajari, tugas yang harus dipelajari, matode pembelajaran, dan perbedaan individual. Oleh karena itu perlu dicari suatu pendekatan serta metode pembelajaran yang tepat agar pemrosesan informasi dapat berlangsung secara maksimal.

Untuk memenuhi hal tersebut guru sedapat mungkin melibatkan siswa dalam proses pembajaran, salah satunya dengan 
memberikan pertanyaan untuk memicu keterlibatan berpikir siswa, sehingga siswa dapat menggunakan dan mengaitkan konsepkonsep yang telah dimilikinya. Bila konsepkonsep tersebut terkait satu sama lain akan terbentuk pengetahuan yang bermakna yang tidak mudah untuk dilupakan.

Salah satu teknik yang dapat membuat siswa benar-benar terlibat dalam proses pembelajaran adalah dengan melakukan wawancara klinis. Dimana dalam wawancara klinis ini siswa akan dibantu untuk menggali pemikiran mereka sendiri, sehingga dengan adanya keterlibatan mereka secara langsung akan membuat apa yang telah mereka pelajari akan membekas di dalam pikiran mereka dalam jangka waktu yang lama.

Dari hasil beberapa penelitian menunjukkan bahwa wawancara klinis dapat digunakan untuk mengatasi kesulitan matematika siswa. Hal ini didukung oleh beberapa penelitian terdahulu, yaitu Chistianti (2012) dan Barunawati (2012). Arias, Schoor, dan Warner (2010, dalam Nurhidayati) menyatakan bahwa teratasinya kesulitan matematika siswa dikarenakan wawancara klinis menjadi sarana untuk guru memahami siswa secara individu.

Untuk subyek A, sebelum diberikan wawancara klinis A mengalami hambatan menyamakan kedua penyebut dengan menggunakan konsep KPK, menentukan pecahan senilai dengan diketahui nilai penyebutnya, dan menyederhanakan pecahan, serta mengubah pecahan campuran kepecahan biasa. Subyek A mengalami hambatan untuk tiap butir soal (soal nomor 1, 2 dan 3). Pada saat wawancara klinis, hal yang dilakukan peneliti adalah membimbing A untuk memahami konsep penjumlahan pecahan pecahan biasa dan penjumlahan pecahan campuran yang berpenyebut berbeda. Peneliti mengingatkan A, jika mendapatkan pelajaran di sekolah, harus dipelajari atau di ulang di rumah lagi agar tidak lupa.
Untuk subyek A, sebelum diberikan wawancara klinis B mengalami hambatan, menyamakan kedua penyebut dengan menggunakan konsep KPK, menentukan pecahan senilai dengan diketahui nilai penyebutnya, dan menyederhanakan pecahan, serta mengubah pecahan campuran kepecahan biasa. Subyek B mengalami hambatan untuk tiap butir soal (soal nomor 1, 2, 3). Pada saat wawancara klinis, hal yang dilakukan peneliti adalah membimbing $\mathrm{B}$ untuk memahami konsep penjumlahan pecahan yang berpenyebut sama, pejumlahan pecahan biasa dan pecahan campuran yang berpenyebut berbeda. Peneliti mengingatkan B, jika mendapatkan pelajaran di sekolah, harus dipelajari atau di ulang di rumah lagi agar tidak lupa.

Untuk subyek G, sebelum diberikan wawancara klinis $G$ mengalami hambatan menyamakan kedua penyebut dengan menggunakan konsep KPK, menentukan pecahan senilai dengan diketahui nilai penyebutnya, dan menyederhanakan pecahan, serta mengubah pecahan campuran kepecahan biasa. Subyek $G$ mengalami hambatan untuk tiap butir soal (soal nomor 1, 2, dan 3). Pada saat wawancara klinis, hal yang dilakukan peneliti adalah membimbing $\mathrm{G}$ untuk memahami konsep penjumlahan pecahan pecahan biasa dan penjumlahan pecahan campuran yang berpenyebut berbeda. Peneliti mengingatkan G, jika mendapatkan pelajaran di sekolah, harus dipelajari atau di ulang di rumah lagi agar tidak lupa.

Untuk subyek $\mathrm{H}$, sebelum diberikan wawancara klinis $\mathrm{H}$ mengalami hambatan menentukan pecahan senilai dengan diketahui nilai penyebutnya, dan menyederhanakan pecahan, serta mengubah pecahan campuran kepecahan biasa. Subyek $\mathrm{H}$ mengalami hambatan untuk tiap butir soal (soal nomor 1, 2, dan 3). Pada saat wawancara klinis, hal yang dilakukan peneliti adalah membimbing $\mathrm{H}$ untuk memahami konsep penjumlahan pecahan pecahan biasa 
dan penjumlahan pecahan campuran yang berpenyebut berbeda. Peneliti mengingatkan $\mathrm{H}$ jika mendapatkan pelajaran di sekolah, harus dipelajari atau di ulang di rumah lagi agar tidak lupa.

untuk subyek $\mathrm{J}$, sebelum diberikan wawancara klinis $\mathrm{J}$ mengalami hambatan menentukan untuk setiap butir soal (soal nomor 1, 2, dan 3). Pada saat wawancara klinis, hal yang dilakukan peneliti adalah membimbing $\mathbf{J}$ untuk memahami konsep pecahan biasa berpenyebut berbeda dan pecahan campuran yang berpenyebut berbeda. Peneliti mengingatkan kepada J jika akan menyelesaikan suatu soal harus teliti, setelah dijawab harus dicek kembali untuk memeriksa apakah ada yang keliru atau salah tulis.

Untuk subyek $\mathrm{O}$, sebelum diberikan wawancara klinis $\mathrm{O}$ mengalami hambatan menyamakan kedua penyebut dengan menggunakan konsep KPK, dan menentukan pecahan senilai dengan diketahui nilai penyebutnya, serta menyederhanakan pecahan. Subyek O mengalami hambatan untuk tiap butir soal (soal nomor 1, 2, dan 3). Pada saat wawancara klinis, hal yang dilakukan peneliti adalah membimbing A untuk memahami konsep penjumlahan pecahan pecahan biasa dan penjumlahan pecahan campuran yang berpenyebut berbeda. Peneliti mengingatkan $\mathrm{O}$, jika mendapatkan pelajaran di sekolah, harus dipelajari atau di ulang di rumah lagi agar tidak lupa.

Dari hasil penelitian yang telah diuraikan, jelas terlihat adanya perbedaan kemampuan awal dengan kemampuan akhir mereka setelah diberikan bimbingan dengan menggunakan wawancara klinis Dari pre test dan post test terlihat juga bahwa untuk masing-masing subyek penelitian terdapat peningkatan hasil belajar, yaitu: siswa A memiliki skor pre-test sebesar 2 dan skor post-test menjadi 10 sehingga terdapat peningkatan sebesar $66,67 \%$. Siswa B memiliki memiliki skor pre-test sebesar 0 dan skor post-test menjadi 11 sehingga terdapat peningkatan sebesar 91,67\%. Siswa $\mathrm{G}$ memiliki skor pre-test sebesar 0 dan skor post-test menjadi 10 sehingga terdapat peningkatan $83,33 \%$. Siswa $\mathrm{H}$ memiliki skor pre-test sebesar 7 dan skor post-test menjadi 12 sehingga terdapat peningkatan sebesar 41,67\%. Siswa J memiliki skor pre-test sebesar 9 dan skor post-test menjadi 11sehingga terdapat peningkatan sebesar $16,67 \%$. Siswa O memiliki skor pre-test sebesar 1 dan skor post-test menjadi 12 sehingga terdapat peningkatan sebesar $91,67 \%$.

Peningkatan dari pre test ke post test ini menunjukkan terjadinya peningkatan hasil belajar yang cukup besar setelah dilakukannya bimbingan mengatasi hambatan penalaran matematis dengan menggunakan wawancara klinis. Perkiraan peningkatan hasil belajar subyek penelitian dikarenakan selama wawancara klinis mereka antusias dalam mengikuti proses wawancara. Hal ini disebabkan karena proses pembelajaran menggunakan wawancara klinis merupakan suatu cara yang tepat untuk dapat mengakomodasi kebutuhan mereka. Di mana pada pembelajaran klasikal kebutuhan tersebut tidak terpenuhi.

\section{KESIMPULAN}

1. Dari analisis kesulitan subyek penelitian pada materi penjumlahan pecahan diperoleh informasi bahwa semua subyek penelitian mengalami hambatan pada materi penjumlahan pecahan dengan penyebut yang berbeda. Hal ini terlihat dari jawaban yang diberikan subyek penelitian pada pre test, di mana mereka dalam penjumlahan pecahan yang berpenyebut beda tidak menyamakan kedua penyebut dengan menggunakan konsep KPK, tidak menentukan pecahan senilai dengan diketahui nilai penyebutnya, dan tidak paham dalam menyederhanakan pecahan, serta tidak pahamnya dalam mengubah pecahan campuran kepecahan biasa, sehingga 
subyek mengalami kesalahan dalam menyelesaikan soal penjumlahan pecahan.

2. Hambatan yang dialami siswa disebabkan karena kurang paham akan konsep, tidak paham akan prosedural pengerjaan dan kurang teliti dalam perhitungan dalam operasi perkalian dan pembagian bilangan bulat yang sebelumnya mereka pelajari.

3. Setelah dilakukan wawancara klinis pada materi penjumlahan pecahan berdampak pada berkurangnya hambatan dan kesalahan siswa dalam menyelesaikan soal tentang operasi penjumlahan pecahan denga penyebut yang berbeda berdasarkan peningkatan hasil post test subyek penelitian.

\section{SARAN}

Disarankan bagi para guru di sekolah diharapkan dapat menerapkan wawancara klinis kepada siswa yang kurang mampu dalam hal belajar.

\section{DAFTAR RUJUKAN}

Arifin, Zainal. 2010. Evaluasi Pembelajaran. Bandung: Jakarta: PT Remaja Rosdakarya.
Arikunto, Suharsimi. 2010. Prosedur Penelitian Suatu Pendekatan Praktik. Jakarta: Bumi Aksara.

Arikunto, Suharsimi. 2009. Dasar-Dasar Evaluasi Pendidikan. Jakarta: Bumi Aksara.

Barunawati. 2012. Penerapan Wawancara Klinis Untuk Mengatasi Kesulitan Belajar Siswa di Mts Mathila'ul Anwar Pontianak. Skripsi: STKIP. Pontianak:tidak diterbitkan.

Buschman, Larry. 2001. Using Student Interviews to Guide Classroom Instruction: An Action Research Project. [On-line] Available: www.eric.ed.gov/ERICWebportal/reco rdDetail. [Akses: 5 Oktober 2013].

Christianti. Tarsila. 2012. Mengatasi Kesulitan Siswa Dalam Menyelesaikan Limit Fungsi Aljabar Menggunakan Wawancara Klinis Di Kelas XI SMA BENADIKTUS PAHAUMAN. Skripsi: STKIP-PGRI Pontianak:tidak diterbitkan.

NCTM. 2000. Principles and Standars for Scohool Mathematichs. American: Library of Congress Cataloguing-inPublication. 